\title{
EL HISTORIADOR ANTE LA TRISTEZA MODERNA: LAS APORTACIONES DE JOSÉ DELEITO Y PIÑUELA A LOS ESTUDIOS LITERARIOS
}

\author{
Begoña Sáez Martínez \\ Departamento de Español de la EOI de Valencia
}

\begin{abstract}
Resumen: En este artículo se estudian las aportaciones del historiador José Deleito y Piñuela a los estudios literarios sobre el modernismo y la crisis de la modernidad en sus obras: La tristeza de la literatura contemporánea (1911) y El sentimiento de tristeza en la literatura contemporánea (1922). Sus análisis a partir del término tristeza como rasgo fundamental, posición preferente del espíritu y común denominador de escuelas y géneros, ayudan a revelar algunas de las implicaciones históricas y estéticas de la literatura europea de fines del siglo XIX. A fin de contextualizar su obra y dibujar el clima intelectual y sentimental de la época, se exploran los valores asignados a la tristeza por algunos autores y críticos del momento hasta llegar a configurar un indicio de la modernidad.
\end{abstract}

Palabras clave: José Deleito y Piñuela, tristeza, modernismo, crisis de la modernidad, cultura de fin de siglo, krausoinstitucionismo.

\section{The historian before modern sadness: contributions of José Deleito y Piñuela to literary studies}

Abstract: In this article we study the contributions of the historian José Deleito y Piñuela to the literary studies on Spanish modernism and the crisis of modernity in his works: The sadness of contemporany literature (1911) and The feeling of sadness contemporany literature (1922). His analysis starting from the term sadness as a fundamental trait, the most common position of the spirit and common aspect of schools and genres, help reveal some of the historic and aesthetic implications of European literature at the end of the $19^{\text {th }}$ Century. In order to put his work in the proper context and describe the intellectual and sentimental climate of the period, we explore the values assigned to sadness by some authors and critics of the time until the manage to configurate a sign of modernity.

Key words: José Deleito y Piñuela, spleen, Spanish modernism, crisis of modernity, fin-de-siècle culture, krausoinstitucionismo.

\section{UNA NUEVA MODALIDAD DEL SENTIR}

La tristeza, la melancolía y el pesimismo son a menudo poéticos. La crisis de fin de siglo XIX dio rienda suelta en literatura a los humores negros. Muchos personajes se vieron sumidos en un estado de malestar universal y dolor insuperable, que bien podía tratarse de un duelo sin razón, como describe Verlaine $(2007,122)$ cuando llora en su corazón como llueve en la ciudad para referirse a esa disposición de ánimo metafísico, el aburrimiento ontológico. Por ello, con acierto Llanas Aguilaniedo en 1899 observa que el alma contem-

Data de recepció: 28 d'octubre de 2016 / Data d'acceptació: 28 de gener de 2017. 
poránea comprende mejor la belleza de la puesta que la de la aurora $(1991,7)$ al tiempo que destaca que el cansancio, la fatiga y fastidio de la época referido a un mismo tipo psicológico se ha traducido en todas las lenguas: spleen, weltschmerz, fithur, lissa, ennui, etc.

En realidad para Llanas se trata de una experiencia de época y no de un mero aburrimiento o sufrimiento especial que afecte a un determinado individuo. Con esta apreciación se reconoce un cambio sustancial. Estamos ante una nueva forma de sensibilidad, un estado emocional y estético vinculado a la crisis finisecular y a la experiencia de la modernidad. Este estado de ánimo, como han analizado Christa Bürger y Peter Bürger, es la situación del sujeto moderno en la medida en que éste se enfrenta a su situación (2001, 204). Por ello, puede hablarse del origen de la modernidad estética a partir del ennui entendido como la situación que soporta toda manifestación artística de la Modernidad, el fundamento oscuro, del que procede el anhelo de que las cosas sean de otra forma (Bürger, 219).

Así trató de explicarlo en 1890 desde las páginas de El País Julián del Casal recurriendo al término de tristeza fin de siglo. A los ojos del escritor cubano este momento lleno de cosas tan contradictorias e inesperadas $(1964,18)$ está lejos de ofrecer cartografías serenas. Por el contrario, la incertidumbre y la desesperación es el signo de unos tiempos que abocan a la falta de fe y, como contrapartida, a una necesidad imperiosa (18) de creer. Una tensión en la que no oculta el temor al ascenso del protagonismo histórico de la clase obrera bajo la forma de las muchedumbres hambrientas y de un gran cataclismo social (18) y que, según su pronóstico, no resolverá la apertura del nuevo siglo. Por ello, frente a la idea de progreso, lo que se observa es un retroceso y un malestar: la "tristeza de fin de siglo", se va introduciendo, como los microbios de una epidemia, en todos los espíritus (18).

También para Valera el momento es pavoroso y lúgubre. Se piensa que nos hemos quedado sin religión y sin metafísica. No hay más que empirismo, ciencia $(1891,157)$. La idea de pérdida y desposesión es importante sobre todo por la huella que imprime en los sujetos. No en vano Freud en "Duelo y melancolía" (1917 [1915]) clarifica que en la pérdida melancólica el enfermo sabe a quién perdió, pero no lo que perdió en él (1992, 243). La pérdida, por lo tanto, se coloca en el yo que se ve empobrecido. Desde esta perspectiva, se desplaza la atención al impacto en el sujeto, un impacto terrible ya que no sabe el coste que implica dicho sentimiento.

En esta línea, cabe entender, como lo hace Allegra, parte del modernismo como una especie de Schola de la acidia poética $(1986,203)$. Este crítico al referirse al mal de Saturno en Manuel Machado, advierte con razón que no es tanto "pesimismo" en sentido propio cuanto un algo de extrañamiento del poeta respecto al mundo (212). Se trata pues del sujeto en crisis con su entorno.

Más allá de los términos empleados, una misma red conceptual asociada a la tristitia sirve para describir el estado de ánimo del hombre moderno ${ }^{1}$. El fin de siglo XIX, como cualquier época de tránsito, se caracteriza por un crepúsculo del entusiasmo y toda clase de pronósticos catastrofistas. Se trata de un claro indicio de desorientación. Lo expresó con acierto Huysmans en Là-Bas (1891) al afirmar que los finales de siglo se asemejan. Todos vacilan y se turban $(1986,311)$. Estamos ante la percepción de que el mundo y el tiempo están desquiciados. La convicción en la experiencia de la modernidad de que la historia se desenvuelve en el modo de la tragedia, puso en crisis el concepto de progreso y

\footnotetext{
1 Sobre los distintos términos (esplín, hipocondría, acedía, languidez, tedio, aborrecimiento, tristeza manía, etc.) asociados al mal del siglo bajo el signo de Saturno, véase Diego y Vázquez (1998, 11-30).
} 
de todos los mitos de la modernidad racionalista y positivista. La cultura del modernismo no podía ofrecer imágenes tranquilizadoras de lo real.

En España la crisis militar y política del llamado Desastre de 1898 fue un hecho complejo y crucial para la dinámica de su historia. Crisis de la legitimidad política de la Restauración, cambios económicos, nuevas ideologías, etc., una crisis, en suma, que afectó a las estructuras sociales, políticas y económicas. No es casual que en 1905, durante su estancia en Madrid, Rubén Darío haga de Don Quijote, el señor de los tristes (1977, 182)2 , encarnando así un estado anímico en consonancia con una atmósfera de desencanto, caliginosa, asfixiante, un ambiente de desesperación, en palabras de González Serrano (1898, s. p.).

Sin duda una oleada de pesimismo irrumpió en la literatura española ${ }^{3}$. Una oleada que, si en un principio puede verse como una moda, la boga del spleen como sustituto de la antigua melancolía romántica y divisa del final del siglo, es el síntoma de una nueva modalidad del sentir. En realidad, la triste melancolía romántica se recrudece, abandona la languidez, se carga de amargura y también de ironía (Diego, 1998, 136). Si en el Romanticismo aún hay fe, esperanza y sueños, ahora imperan la decepción y el vacío. Pero esta situación, en lugar de producir una parálisis creativa, es un acicate para la imaginación. En el poeta de fin de siglo, la melancolía lleva a una convulsión creativa. La amargura del alma, que deviene pesimismo, potencia los estados sensibles e imaginativos propios de la poesía (López Manzanedo, 2010, 114).

Ya lo advirtió Baudelaire en “Alquimia del dolor”. El dolor modifica la percepción del mundo y hace del poeta un alquimista triste que transforma el oro en hierro, el paraíso en infierno o las nubes en sudarios. En efecto, constituye uno de los estados de ánimo explorados por la literatura y el arte. Un escritor de tanto alcance en la época como E. A. Poe había revelado en La filosofía de la composición (1846) que la melancolía es el más legítimo de todos los tonos poéticos $(1973,70)$, el elemento constitutivo de la belleza. De hecho, el spleen es el núcleo del gran poemario Les fleurs du mal. Por su parte, Verlaine en su famoso soneto "Langueur" celebra un arte de la décadence: D'un style d'or où la langueur du soleil danse $(1994,156)$. Existe asimismo toda una iconografía en torno a lo melancólico. La isla de los muertos (1880) de Böcklin, de gran éxito entre pintores y escritores, o las figuras contemplativas de Gustave Moreau, son un buen ejemplo.

Frente a ello, los detractores verán en estas producciones defectos, estupidez y síntomas de degeneración. La obra más emblemática de dicha reacción es Entartung $(1892 / 3)^{4}$ de

2 La "Letanía de Nuestro Señor don Quijote" se leyó en el Ateneo de Madrid el 13 de mayo de 1905 dentro del ciclo de conferencias para celebrar el III centenario del Quijote. Con este poema Darío se suma a la interpretación metafísica despojada del lado cómico -seguida por los románticos alemanes y el cervantismo de fines del siglo XIX- que convierte al caballero en un ente trascendente y melancólico.

3 Sobre esta cuestión véase Lozano Marco, M. A. (2000): Imágenes del pesimismo. Literatura y arte en España. 1898-1930, Alicante, Universidad y el estudio ya clásico de Hinterhäuser, H. (1999): Fin de siglo. Figuras y mitos. Tr. M. T. Martínez, Madrid, Taurus. También análisis específicos como el de Alonso, C. (1996): "Notas sobre el pesimismo activo en la literatura española hacia 1900 (un fin de siglo entre la voluntad y el dolor de vivir)", Anales de Literatura Española, 12, 27-55 y el de Ferri Coll, J. Mª (2009): "Musa enferma: la melancolía en la poesía española de fin de siglo", Frenia, IX, 53-70.

4 Traducido en 1902 como Degeneración. Sobre la crítica española a favor de Nordau véase el artículo pionero de Davis, L. E. (1977): “Max Nordau, 'Degeneración' y la decadencia de España”, Cuadernos Hispanoamericanos, Agosto-Septiembre, 326-327, 307-323, centrado fundamentalmente en Nicolás Salmerón, Fray Candil y Llanas Aguilaniedo. 
Max Nordau, discípulo de César Lombroso. Aquí el fin de siècle es equiparado al fin de raza caracterizado por el desprecio de las convenencias y de la moral tradicionales (1902, I, 9). Para Nordau, el estado del alma contemporánea es la impotente desesperación de un enfermo crónico que en medio de la naturaleza exuberante y eterna se siente morir poco a poco (6). De este modo, se origina un debate sobre el mal del siglo que recorre la espina dorsal de la cultura del momento. Toda una serie de discursos luchan por apresar su sentido hasta configurar un patrimonio cultural. El resultado de todo ello es un tono lúgubre, una conciencia terminal, reconocible tanto en las producciones simbólicas como en el dominio discursivo ${ }^{5}$.

Debido sobre todo a la influencia de Nordau y de Lombroso emerge un doble discurso del modernismo donde la decadencia aparece a la vez como progresiva y regresiva, como regeneradora y degeneradora, como buena e insalubre (Molloy, 2012, 26). Se produce, pues, un elogio y una crítica de la modernidad. Así nos encontramos ante textos, como los de Huysmans, Moreau o Baudelaire, que ofrecen su representación de la modernidad y ante otros que pertenecen a un corpus científico o seudocientífico que denuncian la decadencia presente en las producciones artísticas. Esta dialéctica entre modernidades, más que entre modernidad y antimodernidad, ha sido abordada por Compagnon para quien los verdaderos antimodernos son también, al mismo tiempo, modernos $(2007,19)$. Baudelaire sería el prototipo. De hecho, su modernidad es inseparable de su resistencia al 'mundo moderno’ (Compagnon, 19). En las letras hispánicas, Rubén Darío sintetiza esta resistencia, no solo literaria sino también crítica como pone de manifiesto su respuesta a los planteamientos de Nordau en Los Raros (1896).

\section{LA LOBREGUEZ DE LOS DISCURSOS}

Lo que es indudable es que este clima de fin de los tiempos se instaló en los discursos que construyen la opinión sobre lo real. Por ejemplo, desde el campo de la filosofía, el crítico francés Erasmo María Caro (1826-1887) en Le pessimisme au XIXe siècle: Leopardi, Schopenhauer, Hartmann (París, 1878) ${ }^{6}$, considera que el pesimismo es una enfermedad esencialmente moderna $(1892,31)$ y una filosofía de transición: una crisis y nada más (300), que puede tomar la forma de una experiencia como en Leopardi o la de un razonamiento como en Schopenhauer y en Hartmann. Junto a ellos sitúa a Wagner, el compositor predestinado del pesimismo (124). Para Caro, estas doctrinas desesperadas constituyen algo novedoso y pueden ser objeto de estudio médico, como, por ejemplo, el llevado a cabo por Karl von Seidlitz en Schopenhauer bajo el punto de vista médico, donde el filósofo es des-

5 En la misma línea Cardwell, R. A. (1995): “Médicos chiflados: Medicina y Literatura en la España de fin de siglo", Siglo diecinueve (Literatura hispánica), 1, 91-116, plantea el funcionamiento de los discursos de poder y revisa los debates literarios de la España de fin de siglo: el debate entre "gente vieja" y "gente joven" no será tanto sobre estilos o contenidos literarios, como sobre cuestiones, en última instancia, de poder y control (115). También Raimond, M. (2000): Éloge et critique de la modernité, Paris, PUF, aborda la dialéctica de la modernidad, una dialéctica que va del entusiasmo de los primeros poetas de la modernidad a la inquietud posterior.

${ }^{6}$ En España contamos con la edición parcial El pesimismo en el siglo XIX. Un precursor de Schopenhauer, Leopardi. Tr. A. Palacio Valdés, Biblioteca de Ciencias y Artes, Madrid, 1878. Catorce años después la obra se volvió a traducir y se publicó completa como El pesimismo en el siglo XIX. Leopardi, Schopenhauer, Hartmann, Colección de Libros Escogidos n ${ }^{\circ}$ 58, La España Moderna (Revista IberoAmericana), Madrid s.a. [1892]. Para más detalles puede consultarse <www.filosofia.org > 
crito como un terrible misántropo (286). Como fenómeno patológico y mental este pensamiento triste se atribuye al temperamento, al humor y al carácter hasta el punto de poder ver que es más propio de los pueblos bebedores de cerveza que de los de vino, o bien puede atribuirse a un desequilibrio entre la fuerza de las emociones y la de los movimientos voluntarios, una acumulación de las impresiones en el sistema nervioso cuando éstas son muy vivas y numerosas. Pero tampoco faltan causas morales como la quiebra de las grandes esperanzas intelectuales, la pérdida del ideal político y social o la influencia del positivismo que ha destruido las antiguas creencias. Sin embargo, en su opinión, la ciencia no ha provisto aún de nuevas formas que puedan traducir sus emociones (288) y en consecuencia la solución reside en recobrar el ideal.

En esta línea, no es casual que Henri Beaune en La tristesse moderne (1886), parta del grabado Melancolía de Durero para ejemplificar la imagen de Francia au bord de l'histoire $(1886,7)$, un estado de tristeza inexorable que difiere del ennui de un romántico como Lamartine. Para este magistrado todo radica en una suerte de conspiración de la ciencia, el arte, la filosofía y la literatura contra el ideal y su concepto de belleza como esplendor de lo verdadero. De ahí que el gusto por lo horrible, lo obsceno y lo inmundo y el desprecio por la humanidad característicos de la literatura moderna, sean un indicio de que el gusto puede ser plus dépravé que les moeurs (23). Asimismo, en su opinión, con la ciencia se ha progresado en lo material, pero no en lo espiritual ya que el pesimismo y el escepticismo han llevado a un desinterés por la virtud. Ante ello, propone como remedio recuperar la fe en todos los órdenes: religioso, político, en el futuro o en el prójimo.

Menos esperanzador se muestra Eça de Queiroz en "A decadencia do riso" (1891). Para este escritor la atmósfera moral de su tiempo es tal que se puede decir que volvieron los tiempos de la Melancolía de Durero y se ha perdido el don divino de la risa. El exceso de civilización material, política, económica, literaria y artística lo ha vuelto todo triste, desde la sociedad hasta la literatura, una situación para la que ya no ve posibilidad de retorno: o riso acabou-porque a humanidade entristeceu. E entristeceu-por causa da sua inmensa civilisação. $O$ único homem sobre a terra que ainda solta a feliz risada primitiva é o negro, na África (1937, 209), asevera.

Será, sin embargo, el historiador del arte Hippolyte Fierens-Gevaert un referente destacado en la época. Su obra La tristesse contemporaine (1899), que se tradujo en 1900 al español ${ }^{7}$, constituye una reacción contra la languidez general del mundo intelectual (1900, 13), cuya causa atribuye al espíritu irreligioso. El hombre moderno se caracteriza por su cuerpo anémico, el cerebro fatigado, el alma desilusionada (32). Por ello, la literatura está inquieta en tal grado que podrían volver a esta tierra Byron, Musset y Henri Heine, los ilustres neuróticos del romanticismo, y tendrían piedad de nuestra decadencia espiritual (38). Para Fierens todo se explica por esa decadencia de la vida meditativa, desde los peligros del individualismo a los del colectivismo, desde las revoluciones del siglo vistas como una consecuencia de la incredulidad (25), hasta actos como el leer con exceso (31) que él interpreta como una forma de llenar ese enorme vacío dejado por la ausencia de creencia religiosa. No sorprende que desde otra óptica, en una breve nota publicada en

7 Ya en mayo de 1899 hay mención en La España Moderna (Madrid) dentro de la sección "Revista de Revistas", dirigida por Fernando Araujo, 156-158, y también en Revista contemporánea (Madrid, 1899, $113,440)$. 
Revista General Internacional se afirme que este libro haría buen camino en los claustros y en las sacristías $(1900,61)$ porque ante todo es una propaganda hacia el salto atrás, convirtiendo las ideas modernas al misticismo, bajo pena de considerarse malo todo lo que no vaya por este camino (61).

También desde el campo de la psicología fue abordado el tema. Por ejemplo, Georges Dumas en La tristesse et la joie (Paris, 1900) ${ }^{8}$ celebra las aportaciones de su maestro Ribot y el estudio de las emociones y ve que el melancólico no puede explicarse de forma racional la causa de su abatimiento. Pero ante todo este psiquismo oscuro, inexplicable, y este sentimiento de tristeza es la expresión de una gran sensibilidad y como tal está más presente en literatura. De este modo, el hombre replegado sobre sí mismo, aislado del mundo exterior es más fácilmente un objeto de análisis y observación: la joie n'engendre jamais cette analyse de soi-même si chère aux mélancoliques de la littérature $(1900,117)$.

Por su parte, el sociólogo Émile Tardieu en L'ennui: étude psychologique (Paris, $1903)^{9}$ describe el tedio o aburrimiento como un mal personal formado de fatiga y falta de esperanza, una dolencia de decadencia, aristocrática que atañe a la sensibilidad del sujeto. Constituye, pues, un sufrimiento y un estado subjetivo. A su modo de ver, existe en quienes saben desarrollar el tema en poemas y novelas, en expresar sus alegrías y sus dolores se penchent jusqu'au vertige sur l'abîme sans fond qu'est notre coeur $(1903,4)$ y se remonta al siglo XVIII con el romanticismo de un Rousseau o de un Chateaubriand. Para Tardieu, a diferencia del pesimismo que es una teoría de la vida, estamos ante un malestar individual, de orden metafísico, que ha encontrado su expresión literaria en tiempos recientes, precisamente cuando el hombre ha descendido hasta su interior y ha retrocedido espantado ante su alma vacía.

Estos discursos tuvieron clara resonancia en España sobre todo a través de Francia, auténtico foco de irradiación cultural y de mediación entre la literatura española y las europeas contemporáneas. Así lo revelan no sólo las traducciones, el eco en periódicos y revistas, sino también la huella en aportaciones concretas como las de José Deleito y Piñuela (1879-1957), catedrático de Historia Universal en la Universidad de Valencia desde 1906 hasta que tras la Guerra Civil fue depurado.

Vinculado al espíritu de la Institución Libre de Enseñanza, Deleito fue un historiador comprometido con los problemas de su época, siempre al tanto de las nuevas tendencias historiográficas y culturales. Su producción abarcó campos como el periodismo o la crítica literaria, con un pensamiento sobre la disciplina histórica en consonancia con la reflexión más avanzada antes de que hiciera acto de presencia la escuela francesa de los "Annales" (Ruiz Torres, 2005, 4) ${ }^{10}$. Entre sus obras destacan La tristeza de la literatura contemporá-

8 El libro fue reseñado en Revista contemporánea, 1900, 118. Sobre este tema Dumas había publicado artículos entre 1896 y 1897 en Revue Philosophique, la obra Les états intellectuels dans la mélancolie (Paris, F. Alcan, 1894) y había traducido Les emotions de Lange (Paris, F. Alcan, 1895).

9 Se tradujo al español como El aburrimiento, por R. Rubio, Biblioteca-Científico-Filosófica, Madrid, Daniel Jorro Editor, 1904.

10 Para una semblanza sobre el autor véase Pasamar, G. y Peiró, I. (2002): Diccionario Akal de Historiadores españoles contemporáneos, Madrid, Akal, y sobre todo los estudios de Gallardo Fernández, I. M ${ }^{a}$ (2005): José Deleito y Piñuela y la renovación de la historia en España, Valencia, Servei de Publicacions de la Universitat de València y su tesis doctoral (1992): Un Krauso-institucionista de última hora: José Deleito y Piñuela. Vida, obra y pensamiento, Universidad de València. Es también reseñable el "Homenaje a don José Deleito y Piñuela” que en 1950 publicó la revista Saitabi (35-38, en-dic, 225-254). 
nea (1911) y El sentimiento de tristeza en la literatura contemporánea (1922). La primera es un breve opúsculo, compuesto a partir de un discurso leído en el Ateneo de Valencia y de otras conferencias, en el que se traza un bosquejo del problema de la tristeza en el arte contemporáneo. En un rápido recorrido de escuelas y direcciones estéticas se nos muestra la unanimidad del fenómeno durante los cien últimos años. La segunda es un vasto estudio que pretende dar cuenta de la amplitud y trascendencia del malestar moderno.

Deleito se caracteriza por una interesante actividad receptora y difusora de la cultura extranjera y española. De hecho muchas de las obras anteriormente mencionadas forman parte del corpus manejado para la elaboración de sus escritos. Sus ensayos constituyen una vasta fuente de documentación tanto crítica como literaria. Abarcan desde la exhumación de fragmentos de Nordau, Guyau o Andrés González-Blanco hasta los comentarios sobre Rollinat en Nuestro tiempo (1904) o de Gonzalo Zaldumbide y su primer estudio sistemático sobre D’Annunzio en 1909, sin dejar de lado suculentas citas, como las tomadas de "Notas y ensayos de una traducción de El cuervo, de Edgar Poe" (Helios, XII, 1914), o de los prólogos de Blasco Ibáñez para la editorial Prometeo. Pero además es continua la reproducción de fragmentos literarios que en muchas ocasiones sustituyen al comentario, lo que conforma no solo una historia literaria sino también una antología de textos que configuraron la cultura del modernismo, muchos de ellos hoy caídos en el olvido.

\section{JOSÉ DELEITO Y PIÑUELA ANTE EL MODERNISMO: LA CRISIS DE LA MODERNIDAD}

Ya en 1902 Deleito participa en el debate periodístico sobre el modernismo que Gente vieja abrió en forma de concurso. Que el modernismo era una realidad artística a la altura de 1900 lo demuestran las polémicas que suscitó en las revistas y la ansiedad por definirlo y delimitarlo. En 1900 Madrid Cómico había lanzado una encuesta al respecto. En el caso de Gente vieja, el lema del concurso: "Arte y progreso", es todo un signo de la orientación de una publicación que tenía como subtítulo: "últimos ecos del siglo XIX" y que fue considerada como el bastión del antimodernismo.

Para Deleito, la febril actividad, el continuo cambio $(1902,1)$ que caracteriza a la sociedad tiene trasunto en el arte. Como toda época de transición, el momento presenta $\mathrm{cri}$ sis violentas, confusión de ideales, vagos anhelos, crepúsculos de un mundo próximo a hundirse envuelto en sudario de sombras, y albores de una civilización futura (1). No en vano, ve el modernismo como una disgregación de fuerzas, una desintegración orgánica, que corresponde a la desintegración social (2).

El historiador es muy consciente de asistir a una de las transformaciones más críticas $y$ difíciles (2) del arte como ponen de manifiesto sus signos caracterizadores: la anarquía, el desprecio a toda autoridad, el predominio individualista, la variedad de ideas y formas o la búsqueda de emociones estéticas desconocidas. Por ello, el modernismo incluye a estetas, simbolistas o decadentistas. No hay diferencia. Algo muy importante pues posteriormente la historiografía literaria española tratará de sanear el modernismo de todo su contagio con el decadentismo.

En su enfoque la huella de Nordau, como en la de tantos estudios del momento, es innegable: todo en el modernismo lleva el sello de la decadencia y el agotamiento (2). De ahí la necesidad del contrapeso de una regeneración puesta la esperanza en un superhom- 
bre que unifique y oriente con un dogma artístico este modernismo brumoso (2). Sin embargo, a cada intento de construir un arte con la mirada puesta en el siglo XIX donde el concepto de autoridad, norma y estabilidad son principios clave y la historia humana es entendida como progreso, se le opone el siglo XX marcado por toda una serie de líneas de fractura. Quizá, por ello, ante la inutilidad de buscar una escuela, rota la esperanza en ese superhombre que sirva de faro, Deleito opta por marcar en la tristeza la línea directriz del arte contemporáneo. Se trata, a su modo de ver, de una preocupación o enfermedad universal que ha generado tal número de escritos que podría formarse una copiosa antología del nihilismo tétrico: el florilegio del dolor de nuestra época, ante la vacía inanimidad de cuanto existe $(1911,8)$. Así lo expresa el artista moderno en sus siluetas doloridas o en los paisajes melancólicos, en las melodías de honda tristeza o en los poemas lúgubres y las novelas sombrías que se destacan en el escaparate del librero por sus títulos quejumbrosos y sus portadas grises o espectrales $(1911,17)$. Por esta razón, concluye que autores tan diferentes como Hugo, Zola, Tolstoi, Ibsen, Maeterlinck, Sundermann, Gorki o Verlaine están emparentados por el nexo común de la psicología del dolor y el pesimismo.

\section{EL HISTORIADOR Y LA TRISTEZA DE LA MODERNIDAD}

Los estudios de Deleito no están concebidos como una historia literaria al uso. Circunscritos a las letras de mayor resonancia (francesa, inglesa, italiana, alemana, escandinava y rusa), rastrean de forma minuciosa un motivo clave desde el último tercio del siglo XVIII hasta el momento. El interés de su enfoque reside en tres aspectos: establecer cortes literarios basándose en la marca distintiva de la negación y de la protesta contra la sociedad y contra los antiguos cánones; atender escrupulosamente a sus distintas manifestaciones y, por último, abordar específicamente el modernismo. Aunque el catedrático anunció que escribiría un volumen especial dedicado a España, Portugal e Hispanoamérica, con el título de La tristeza literaria del pueblo ibero $(1922,8)$, no tenemos constancia de que viera la luz. En cualquier caso, lo interesante de su perspectiva es la vastedad de información sobre la literatura europea y su relación con las letras peninsulares.

Como observa Esteban Mateo, se aproxima a la europeización a través de la investigación histórica y de la Institución Libre de Enseñanza (1990, 99). Su trabajo en los Archivos de Valencia, Madrid, Alcalá, Bayona, Burdeos, París, Bruselas o Ginebra muestran ese aperturismo. De hecho, en su ensayo de 1911 España no queda aislada de la cultura internacional. Por el contrario, lo que se ve como achaque de la ibérica tiesura y oriental languidez es en realidad una señal de los tiempos, un indicio del malestar que oprime y asfixia a la psiquis moderna (1911, 3). A ello contribuye el cosmopolitismo que hace seguir a los países de mentalidad más fuerte, o más a la moda (3), como sucede con los países del Norte cuyas brumas atmosféricas armonizan bien con las brumas espirituales que ensombrecen el pensamiento contemporáneo (21) hasta dominar y orientar el panorama literario. En las letras españolas se cumplen idénticas leyes (40). Las visiones hórridas del romanticismo, la desesperación presente en la poesía o el complejo y actual estado de alma, dolorido por las tristezas finiseculares (43) de las novelas de Galdós o Pardo Bazán, desmienten la supuesta alegría española.

Este malestar se debe a causas externas como el maquinismo, el desequilibrio económico o la crisis sociopolítica, e internas como la sensibilidad enfermiza, la fiebre del aná- 
lisis, el escepticismo, la obsesión de la crítica, el exceso de culto al yo, el aburrimiento o la sed de bienestar, todo lo que hace, en suma, del hombre actual un atormentador de sí mismo. Además, el dolor moderno, ese terrible "tedium vitae" de los pueblos decrépitos y gastados (7), tiene como síntomas la ausencia de fe, el desdoblamiento del yo en actor y espectador, la manía de vacilación, la parálisis de la voluntad, el disgusto de sí mismo o el hastío y fatiga de una vida sin objeto ni ideal. Todo ello configura ese nuevo mal del siglo diagnosticado por Nordau y estudiado por Tardieu en El aburrimiento y que Deleito cita por extenso para ilustrar de qué manera el espíritu crítico, el análisis, el escepticismo y la muerte de Dios moldean la imagen de un mundo que sucumbe al horror de vivir y busca olvidarse momentáneamente del fastidio a través de la intoxicación alcohólica y el desenfreno erótico (5).

De este modo, todo el arte moderno es triste porque la vida que lo engendra también lo es. Por ello, aunque el artista se abisme en el estudio de su yo más íntimo (4), los males nuevos imprimen ese gesto doliente a todas las producciones. En este estado de decadencia el alma moderna adopta la forma del laberinto (4) descrita por Nietszche. Aunque la ciencia ha suavizado el dolor físico, el sufrimiento psíquico se ha intensificado. La subjetividad, el inconformismo y el escepticismo se han incrementado: una proyección subjetiva de nuestro ser, cada vez más sensible, más analizador del mal, menos resignado y fuerte para sufrirle, más rebelde a imposiciones extrañas, más ansioso de felicidad, y más desconfiado de obtenerla (4), describe.

Asimismo la actividad de la vida moderna ha creado una generación agotada de neurópatas, abúlicos y tristes [...] sin rumbo por la vida (5). Este mal que para muchos es una patente de artista refinado y una distinción aristocrática (5), para Deleito es algo ridículo y enfermizo. Aun así, no descarta que esta sensibilidad hiperestésica puede aguzar las facultades de observación y hallar en las almas y en las cosas íntimos repliegues, tenues matices, sordos latidos, ocultas vibraciones, novísimos aspectos (5), antes ignorados.

Otro factor clave es el desencantamiento del mundo. La razón y la ciencia con el examen al microscopio (5) han conducido a una inmersión en la pura realidad y a una crisis de fe. Y así el dolor es un compañero tan familiar que lleva a sentir bajo su caricia letal una delectación morbosa (9), o bien a optar por el suicidio. Pero este sufrimiento contemporáneo no es solo un problema psíquico sino también social ya que puede llegar a hacer una exaltación desmesurada y rebelde de la personalidad (12), como sucede en el anarquismo y su aspiración megalómana de destruir la sociedad actual, para fundar sobre sus escombros un quimérico paraíso (12).

Todo ello explicaría que estos problemas hayan sido abordados desde distintos campos intelectuales y con diferentes resultados. Mientras la ciencia busca un remedio, el pesimismo los declara incurables. Esta divergencia sería también una muestra de la complejidad del pensamiento moderno, auténtico océano tumultuoso, donde las olas encontradas se combaten (13). En su opinión, al haberse roto el equilibrio entre teoría y práctica, el ideal que servía de norma es ahora ondulante y movedizo, lo que causa contradicción e impotencia:

el espíritu siente de manera alternativa los furores y los desmayos, la desesperación y el abatimiento, de quien cree tener en su inteligencia la palanca de Arquímedes para remover el mundo, y, al ir a emprender la ciclópea labor, no halla sostén firme para aquélla, ni vigor en su voluntad, ni calma en sus nervios (13). 
Pero este pesimismo incluso puede proclamar con Hartmann el suicidio cósmico hasta penetrar en la juventud pensante, que además se nutre de lecturas tétricas. De hecho, ello ha configurado un prototipo de individuo en cuyos rasgos físicos y comportamiento están impresas las marcas de la crisis con el entorno:

una figura escuálida, enteca, de tez marchita y exangüe, de mirada torva o lánguida, de expresión tediosa y displicente: llevan en el rostro el hastío de una vida que casi no han comenzado a gustar. Alardean de su decadencia, convierten en exquisitez su neurosis, y alejan todo pensamiento de salud y vigor. Viven orgullosos [...] en el fondo de una bohemia negra (17).

El retrato es revelador. La tristeza y sus marcas se señorean de la escena en que se ubican los cuerpos. Sobre estas figuras se edificarán muchos textos literarios que cuestionan el concepto de normalidad e identifican en lo decadente un nuevo territorio. Tomemos como ejemplo "El amante de las torturas" (1893) de Julián del Casal. Aquí las huellas de cansancio, de agotamiento y hasta decrepitud $(2003,76)$ dan el aspecto de convaleciente a un joven que se martiriza para conjurar el 'spleen' (78). El sufrimiento se convierte en voluptuosidad. Sin embargo, frente al discurso trágico de Deleito o al seudocientífico de Nordau, se opone la risa del escritor que ironiza sobre los efectos perniciosos en el joven de las lecturas, en su mayoría obras decadentes y sangrientas.

En este sentido, es lógico que el historiador reclame la serenidad clásica frente al fondo atormentado e inquieto del arte contemporáneo. La diferencia reside en la brecha abierta por la exploración psicológica para profundizar en la vida interior. Frente a los héroes clásicos dueños de sí mismos, los modernos son los degenerados, alcohólicos y erotómanos de Zola, que nos producen una horrenda visión de hospital; los sombríos vagabundos de Gorki, o los golfos, mendigos, desequilibrados, parásitos y rufianes (22) de Baroja. Es el desasosiego que encarnan Silvestre Paradox o Fernando Ossorio, pero también es el tedio que se apropia del espacio en Los pueblos de Azorín o en El poble gris de Santiago Rusiñol: sólo spleen, impresión de vida aldeana tediosa, soñolienta y triste (23).

Con todo, los tipos predilectos de la literatura moderna padecen los dolores y la tortura de su época. Seres inadaptados, pesimistas, sin ideal, sin fe, sin voluntad, con un disgusto de la vida y obsesionados por la nada y la muerte. Personajes hipocondríacos, misántropos y sensitivos que tienen por precursor a Obermann, aunque también son un referente la novela realista y naturalista o los protagonistas de Ibsen o Hauptmann en su lucha inútil por desarrollar su yo interior. Pero entre todos ellos sobresale Des Esseintes, el más representativo del decadente, en quien se unen todas las neurosis, aberraciones y excentricidades de un espíritu lóbrego, minado por el spleen (28). Este hombre-símbolo (28) muestra los últimos confines posibles del malestar y del aburrimiento.

También en España, aunque a su modo de ver no se llegue a los delirios (29) del decadentismo francés, abundan estos tipos complejos y peculiares: los escépticos de Baroja; el intelectual aburrido de La voluntad y de Confesiones de un pequeño filósofo o el hombre atormentado de La Quimera. E igualmente siguen el mismo rumbo los escritores jóvenes con su gusto por los tipos descreídos, abúlicos e hipocondríacos. De este modo, la literatura moderna perfila y ahonda en todos los repliegues psicológicos hasta constituir una sutil inquisidora del dolor, que se extasía ante los panoramas sombríos y las almas atormentadas, acumulando tintas obscuras o siniestras sobre la misma impasible realidad (31). 
Asimismo Deleito advierte otro cambio significativo, esta vez relativo al tratamiento del amor: la degeneración de lo erótico. Este aspecto puede adquirir una diversa gama de tonos: el enfermizo espasmo de raza histérica (23) de las novelas de Zola, las inmundas aberraciones sexuales (23) de las Claudinas de Willy, la necrofilia de satanistas y decadentes o la voluptuosidad sádica de Baudelaire o de Swinburne. Pero también se puede observar en la obsesión atormentadora por el análisis minucioso y sutil (24) del psicologismo de Sthendal y Bourget, o en el misticismo erótico (24) de la novela galante y de los pedestres pornógrafos (24). Como vemos, recoge todas las variantes del tema e incluso enumera las diferentes modalidades de la llamada novela galante: los personajes ansiosos de ideales amorosos inaccesibles de la obra de Felipe Trigo, la asociación morbosa del amor con la sangre de muchas narraciones de Eduardo Zamacois, o toda una serie de escritores que han convertido en fuente de ingresos la sensualidad de cierto público (24).

Ante este nuevo erotismo, su postura es clara. Le resulta enervante y triste pues deja frío el corazón y desolado el espíritu (24). Así lo manifiesta la obra de Gabrielle D'Annunzio, el más erótico de los modernos (24). Su lectura es reveladora. Ve Intermezzo di rime como un poético breviario de la sensualidad (24) que lleva al desencanto del placer y que se resume en su famosa queja "tristezza atroce della carne immonda". En cuanto a La quimera y Elegías romanas, le parecen que destilan la amarga experiencia de los goces ya gustados. Y obras como Il piacere, L'Innocente e Il trionfo della Morte trazan la eterna unión de lujuria y dolor, amor y muerte, con pinceladas magníficamente sombrías (26).

Deleito no es ajeno al cambio de paradigma que supuso el romanticismo y su continuidad literaria. La negación y la protesta contra la sociedad y contra los antiguos cánones que ocasionó la revolución estética del primer tercio del siglo XIX, constituye el signo de la literatura contemporánea en sus más variadas direcciones. En el caso del realismo tomaría forma en la exploración de lo vulgar de la vida cotidiana que saca a la luz pequeños dramas y miserias. Por lo que respecta al naturalismo, se puede ver en el hecho de que el elemento fisiológico funciona como ley primordial que reduce la vida a un simple juego de oscuros instintos. Pero también la reacción neoidealista no estaría exenta de estos signos. Cita como ejemplo el misticismo de Tolstoi en el que se diviniza el espíritu haciendo surgir una vaga religiosidad que aumenta los desfallecimientos del alma. El mismo eco de opresión y disgusto le causan los dramas de Bjornson o Sudermann, el teatro siniestro y estremecedor (37) de Maeterlinck o los personajes torturados de Ibsen de quien Oswaldo en Los espectros (1881) es a su juicio una buena muestra de esta negatividad:

¿Hay nada más sombrío que aquel Oswaldo, epiléptico sin redención, de alma paralítica, que, sostenido por el materno regazo protector, sufre las angustias de un fin de raza, que se ahoga bajo las brumas noruegas, y llama al sol con desgarrado acento en sus convulsiones espasmódicas? (36).

Pero esta inquietud también se manifiesta en el teatro de los pueblos latinos. No se le escapa al crítico que aunque sea menos sistemático en su lobreguez, revela igual conturbación psíquica y social. Este teatro analiza las graves crisis morales y económicas, descubre la complejidad de las almas sensitivas o expresa, como D'Annunzio, el morboso influjo de la pasión (36).

Sin embargo, al llegar a las últimas corrientes dominantes en todos los países, las diferentes direcciones del modernismo (28), aprecia un cambio importante con respecto al ro- 
manticismo. Los signos negativos se han intensificado y una tristeza más enfermiza y neurótica (38) inspira las producciones. Dos elementos son clave. Por un lado, el individualismo extremo, gozoso en su mundo ajeno a todo influjo exterior donde depurar exquisitamente sus más refinadas impresiones artísticas (38). Por otro, la voluntad de renegar y atentar contra la naturaleza como manifiesta la escuela decadentista y escritores como Wilde, Laforgue o Villiers, que, en su opinión, han inundado la literatura con obscenidades, delirios sangrientos y aterradoras quimeras, hallando una delectación morbosa en todo lo horripilante y corrompido (39).

Por ello, modernistas y decadentes representarían en su fase más aguda y morbosa la tristeza y el dolor de la época. Dos obras lo manifiestan a todas luces: Las flores del mal, una apoteosis grandiosa y terrible del pesimismo (39), un poemario que juzga pestilente (39), y las Neurosis de Rollinat, un tristísimo ejemplo del pernicioso ejemplo que puede producir su escuela macabra, pereciendo él mismo hace ocho años, víctima de su vesánico delirio (39). Ante esta literatura de insensatos satanistas (39), que desde Baudelaire, han hecho del mal un dogma, el catedrático sólo ve un arte malogrado.

La lectura unilateral de estas obras es clara. El crítico se queda en la superficie de estos textos que no se acomodan a la cultura clásica y su imagen de belleza. Tal es el caso de su reacción ante obras como La Chanson des Gueux y Blasphémes en las que Richepin idealiza el crimen y hace de la blasfemia un elemento poético, Vice suprême de Péladan donde se sublima el vicio, Le jardin des supplices de Mirbeau en la que se paladea el espectáculo de las más atroces torturas, o textos que restauran el culto medieval al Diablo, al modo de Barbey d'Aurevilly. Ante estas representaciones, la literatura contemporánea es un desfile siniestro de neuróticos o alienados que afecta no sólo a los personajes de ficción sino también a los autores reales. Por ello, puede aplicar el diagnóstico de Max Nordau: el arte moderno es un arte degenerado y, en consecuencia, constituye más un patrimonio del psiquiatra que del crítico.

En cuanto al eterno problema de la influencia de la literatura en la sociedad o a la inversa, la respuesta le resulta vana. El que hayan influido los autores pesimistas en el público produciendo una intoxicación literaria de perversiones y desalientos (40), o, en caso contrario, el público degenerado de las grandes ciudades sobre poetas y novelistas, queda para el historiador sin resolver.

\section{EL SENTIMIENTO DE TRISTEZA}

En 1922 Deleito complementa asombrosamente su estudio para exponer el proceso histórico de la tristeza literaria originado en el romanticismo y lo hace por autores y direcciones estéticas. Esta cara oscura de la modernidad que explota aspectos como el orgullo satánico, las pasiones borrascosas, la impiedad, el tedio, lo feo y anormal, el culto al mal y al horror, el disgusto de la vida o la obsesión por la muerte, entre otros, es la que las escuelas posteriores han renovado e intensificando de distinto modo. Las referencias se multiplican para volver sobre el problema de la estética del dolor contemporáneo. Siguiendo las tesis de Louis Estève en L'Hérédité romantique dans la Littérature contemporaine (1914), considera que es un producto de terribles psiconeurosis que puede clasificarse en tres tipos: el mal del crepúsculo (la melancolía de las horas de penumbra), el mal de la provincia (el deseo del éxodo ante el fastidio de lo conocido) y el mal del más allá (la nostalgia de lo desconocido). 
La perspectiva esbozada en 1911 se define con mayor claridad en su análisis de la tristeza filosófica de los parnasianos y de la tristeza del horror de Poe y Baudelaire. Serán sobre todo estos dos escritores y su gusto morboso por lo horrible, lo que más le inquiete. Su arte alucina la fantasía, hiela la sangre y hace trepidar los nervios con el espasmo del terror $(1922,153)$. De un lado, examina la truculencia sensacional de Poe y su visión de la belleza de la melancolía y de la muerte a partir de citas de la Filosofía de la composición y de El cuervo. De otro, ahonda en las visiones macabras de Baudelaire, el cantor de la muerte (157), profeta y pontífice del satanismo y del decadentismo, las dos tendencias literarias más extraviadas (159) del momento.

Es muy significativo que al ocuparse del poeta maldito y del decadentismo remita a los famosos comentarios de Paul Bourget en Essais de psychologie contemporaine (1883) y lo haga con ciertas reservas. Esta obra fue una prueba clara de la toma de conciencia de la existencia del movimiento decadente en Francia y además aportó toda una teoría de la decadencia. Deleito en principio no rebate la idea de Bourget de que todas las decadencias históricas encierran personalidades superiores en riqueza intelectual y sensitiva pero muestra ciertas reservas al verlo como una forma de justificar la inspiración enfermiza de este arte. Es más, este crítico es en su opinión el más comprensivo e indulgente para todas las aberraciones artísticas (208). Frente a su visión de este nuevo estado del alma marcado por el dolor y el pesimismo, Deleito lo ve como excentricidad, inquietud y sombra (209). La postura es clara. Para no pecar de reaccionario ni de demasiado moderno, busca una posición intermedia con la que digerir los elementos más controvertidos y, en consecuencia, malsanos de esta estética doliente que en su vertiente decadentista tuvo como maestro indiscutible a Baudelaire. Y lo fue sobre todo por glorificar lo artificial, decrépito, corrompido y horripilante; todo lo que es enfermedad, muerte o dolor (161) haciendo así del decadentismo una ejecutoria de superioridad exquisita, elementos a todas luces problemáticos.

Asimismo, que el periodo es muy complejo es indudable. A la fase de plenitud del programa realista sucede otra etapa caracterizada por la convivencia y mezcla de tendencias que se prolonga durante unos veinte años. Para el historiador esta neurótica inquietud finisecular (208) se traduce en múltiples escuelas: naturalistas, satánicos, decadentes, estetas, simbolistas, romanistas, sensitivos, orientalistas, impresionistas (208). Ahora bien, su actitud varía ante los supuestos y resultados artísticos. Por ejemplo, la nota doliente intensificada por la escuela naturalista y la crudeza de Zola, no le resulta inmoral. Por el contrario: las negras pinturas de la sensualidad y el vicio, lejos de mostrarlos apetecibles, los hace siniestros, hórridos y repugnantes (217). Otra, por tanto, es la tristeza patológica y egotista.

Por ello, dentro de la corriente neoidealista engloba de nuevo bajo el concepto de modernismo a las principales agrupaciones literarias: prerrafaelista, simbolista y decadente, el teatro de Ibsen, Sudermann, Maeterlinck y D’Annunzio, o la novela rusa. Como producto de una sociedad envejecida y agotada (222), esta literatura acoge diversas formas de la superstición que pueden combinarse con una sensibilidad morbosa y adoptar una vaguedad crepuscular, incoherencia infantil o misticismo alucinado (223). Sobre estas valoraciones es claro que pesa mucho la voz de Nordau, a quien además cita por extenso. Sin embargo, su toma de partido es otra al plantear que hay que deslindar lo patológico de lo ficticio. En esta amalgama de direcciones literarias hay de todo. Puede ser un producto sincero de la neurosis, imitación servil de la moda, refinamiento del arte (223), pero también, y aquí reside una observación importante, una humorada de gente alegre, que aspira sólo a dejar pasmado, a fuerza de truculencias o salidas de tono, al pacífico y profano lector (223). 
No niega, en consecuencia, que todo dependerá del tipo de lector que se enfrente a estos textos. Esto explica que ante Oscar Wilde deje claro que obedecerá a la perspectiva del crítico para valorarlo como un testimonio de degeneración o bien como la pose de altivo humorista (227). Su lectura le provoca una impresión malsana y desalentadora (227). Estamos, por tanto, ante una impresión, algo subjetivo como el propio sentimiento de tristeza del que hace gala esta literatura y que la poesía simbolista francesa con Verlaine o Laforgue ha acentuado hasta proyectarse a partir 1880 en todas las literaturas.

Pero entre los grupos en que se descompone el movimiento modernista de 1880 a 1900 , su foco de atención recae sobre los más lúgubres y morbosos: el decadentismo y el satanismo. Escritores como Rollinat, Rachilde, Villiers de l'Isle Adam, Barbey d'Aurevilly, Péladan o Huysmans conforman una estética de la monstruosidad (260), que en España tuvo como traductor y apologista a Ricardo Baeza. De ahí que no deje de lado la importancia de la voluptuosidad que, como Proteo, penetra y devuelve bajo mil formas distintas (368) la literatura contemporánea y es síntoma elocuente de los tiempos. Entre esas formas han culminado las amargas y violentas, antinaturales y patológicas (368). Deleito cita, como muestras, a un exquisito cincelador de todas las depravaciones (357) como Jean Lorrain, a un elegante exhumador de todas las perversiones eróticas del mundo antiguo (357) como Pierre Louÿs, o la senda abierta (355) en las letras españolas por Felipe Trigo.

Con todo, el catedrático considera que esta literatura eleva el amor al paroxismo, lo desvía por sendas enfermizas de malestar y agotamiento y enerva el espíritu con las torturas de la carne en fiebre, condenada a padecer para gozar (358). La descripción es muy reveladora y explica su desagrado ante novelas que como las de Octave Mirbeau recrudecen lo truculento, la obscenidad y el sadismo con el objetivo de épater le bourgeois. Por esto, no sorprende que algunas páginas de El jardín de los suplicios le parezcan que rebasan la medida de lo horripilante, hasta hacerse de lectura imposible (380) o que Diario de una camarera le resulte un libro verde y libertino.

\section{EL RETORNO A LA SERENIDAD Y LA MELANCOLÍA DEL HISTORIADOR}

Hacia 1895 se opera en Francia una reacción que aboga por una restauración ética y espiritualista con una vuelta a la normalidad, al equilibrio, a la sinceridad, a los sentimientos humanos, a las preocupaciones sociales y a la democracia (401). De este modo, a partir de 1902 se abre una corriente de reconciliación con la vida y la alegría a la que también se acogen escritores como Barrès, Verhaeren, el propio Mirbeau, Adam o France, y que se extenderá a los demás países.

Deleito no soslaya que esta anarquía literaria del siglo XIX, contenida apenas por el simbolismo, se desborda de nuevo con las vanguardias artísticas. Pero tampoco puede obviar la influencia vigorosa de la Primera Guerra Mundial en la literatura. A su modo de ver, la diferencia radica en si nos situamos ante una pose o bien ante una realidad. En las postrimerías del siglo se buscaría por puro efectismo (431) la nota quejumbrosa y abatida hasta dar en el decadentismo la nota aguda de la impotencia (413). Frente a ello, la crueldad de la guerra ha tendido mantos de luz, irisados por todas las fulguraciones del patriotismo, para cubrir el horror de millones de cadáveres descompuestos (431).

El afán por explicar por razones históricas y sociológicas la tristeza de los textos le lleva a esa dicotomía. Por ello, quiere ver el radicalismo de las obras simbolistas y deca- 
dentes y su efecto desagradable en el lector como una pose o moda pasajera y no como un gran fenómeno estético y culminación de un proceso histórico. Y esto, a pesar de que él mismo es consciente de que en la tristeza romántica se encuentra latente y en embrión toda la tristeza literaria moderna. Su pormenorizado estudio de 1922 es una muestra de ello, sin duda.

Pero ¿cómo se puede digerir desde presupuestos idealistas y la confianza en el progreso una poética como la del decadentismo, un arte estilístico como el modernista cuya primera ruptura se opera en el romanticismo y en el que, como anunció Victor Hugo, la musa moderna mira las cosas desde otros lados y ve que en la creación no todo es humanamente bello? Algo, en efecto, se ha desbordado y a pesar de las esclusas críticas, es imparable. Ya no hay vuelta atrás. La imaginación, concepto clave en Baudelaire, como el sueño de la razón engendra monstruos. La alegría bonachona del burgués se enfrenta al dolor moderno. Frente al buen gusto de una burguesía timorata y conservadora que quiere ocultar los desechos sociales de sus progresos, el arte llamado triste convoca en sus páginas lo feo, lo deforme, lo repulsivo, lo mórbido, el mal o la voluptuosidad que tanto espantan. No en vano, en "De invierno", poema de Azul (1888), Rubén Darío parece recordar el refugio en ese reino interior del hogar familiar, refinado y confortable. Sin embargo, el sujeto lírico que entra sin hacer ruido en la casa y deja su abrigo gris mientras cae la nieve va al encuentro de una mujer que tiene más de Venus de las pieles que de santa esposa.

Ante este estado de cosas, el optimismo de Deleito, en la línea de las ideas liberales y krausoinstitucionistas, es evidente. La lectura de los textos simbolistas y decadentes desde su efecto desagradable en el lector es una prueba innegable de su posicionamiento ante el discurso de la historia y el discurso de la ficción. Cuando el modernismo renuncia al logro de efectos agradables y se pone al servicio de lo desconsolador, el historiador no solo expresa su nostalgia de un arte imitativo que proporcione deleite, sino que además se reafirma en su confianza en el advenimiento de una sociedad nueva más libre y más justa (440).

Con la mirada puesta en el futuro y no en el pasado, el catedrático no cede a los juicios conservadores de Fierens-Gevaert, que aboga por el retorno a una ingenua fe católica. Por el contrario, busca una reacción optimista y sin sustraerse a la lógica evolutiva de la historia apuesta, como Caro, por el carácter transitorio del pesimismo moderno. La tristeza vivida primero y saboreada después (435) se les presenta como un fenómeno accidental. Por esta razón, para combatir este estado crepuscular, que marca el tránsito de la sociedad de ayer a la de mañana (438), se necesita de una tonificación espiritual como la que proclama el propio González Serrano en Preocupaciones sociales: Contra la anemia, hierro; contra el mal del siglo, fe en el ideal (441). De este modo, la cura del escepticismo pasaría por vigorizar el ideal y buscar la acción y la afirmación. En suma, hay que rasgar el velo de sombra para recobrar el humor y la alegría de vivir. Y así con el saneamiento de las almas (445) y la mejora de las condiciones materiales de la vida piensa que la literatura también podrá hacerse más alegre. La terapéutica es clara:

Restauremos en nuestras almas el antiguo, el bienhechor, el pagano culto de la alegría, y en la Literatura, cubierta aún por nubes tempestuosas, podrán volver a lucir días claros de sol (446).

Como intelectual liberal, Deleito pone el pie en la roca para mirar el horizonte brumoso y su idealismo le lleva a afirmar los más altos valores espirituales, de los que no está exenta la alegría. ¿A fin de cuentas no se consideró pecado la tristeza? 
A todas luces, su libro de 1922 es insólitamente competente, rico en sustancia histórica, de carácter abarcador y generoso en lecturas y referencias. Independientemente de la solución propuesta, su esfuerzo de clarificación y comprensión del fenómeno es enorme y, ante todo, pone en evidencia cuán decisivo ha sido para la experiencia de la modernidad el potencial contemplativo desplegado por quienes sintieron la desilusión de las ideologías del progreso, con una trascendencia para la literatura que fue más allá de una superficial celebración de la derrota. La idea de progreso y la fe en la capacidad de mejoramiento del hombre y de la humanidad empieza a tambalearse con los decadentistas y simbolistas, y a partir de ahí el número de pesimistas se irá multiplicando ante una Europa en la que ya ha desaparecido el valor de lo ideal y de lo absoluto y está condenada a la derrota histórica.

Frente a ello, Deleito parece agarrarse a la roca en busca de un arte idealista futuro. Sin embargo, al igual que el ángel de la historia de Benjamin, que observa con los ojos desorbitados un pasado de catástrofe única, de ruina sobre ruina, la roca de Deleito también está abatida por una tempestad que empuja incontenible hacia el futuro (Benjamin, 2008, 310). Y en ese afán imposible emerge con más fuerza la propia melancolía del historiador removiendo en las cenizas con el anhelo de que las cosas sean de otra forma.

\section{BIBLIOGRAFÌA}

ALLEGRA, G. (1986): El Reino interior. Premisas y semblanzas del modernismo en España. Tr. V. Martín Pindado, Madrid, Encuentro, 410 p.

BEAUNE, H. (1886): La tristesse moderne, Paris et Lyon, Delhomme et Briguet, 58 p.

BENJAMIN, W. (2008): "Sobre el concepto de historia", en Obras completas, Tr. A. Brotons, Madrid, Abada, I, 2, $370 \mathrm{p}$.

BÜRGER, C. y BÜRGER, P. (2001): La desaparición del sujeto. Tr. A. González, Madrid, Akal, $344 \mathrm{p}$.

CARO, E. M. (s.a. [1892]): El pesimismo en el siglo XIX. Leopardi, Schopenhauer, Hartmann, Madrid, La España Moderna (Revista Ibero-Americana), Colección de Libros Escogidos nº 58, 303 p.

CASAL, J. del (1964): Prosas, La Habana, Consejo Nacional de Cultura.

CASAL, J. del (2003): "El amante de las torturas", en: D. Phillipps-López (Ed.), Cuentos fantásticos modernistas de Hispanoamérica, Madrid, Cátedra, 75-80.

COMPAGNON, A. (2007): Los Antimodernos, Tr. M. Arranz, Barcelona, Acantilado, 252 p.

DARÍO, R. (1977): "Letanía de Nuestro Señor don Quijote”, Cantos de Vida y Esperanza, México, Editores Mexicanos Unidos, 188 p.

DELEITO Y PIÑUELA, J. (1902): “¿Qué es el modernismo y qué significa como escuela dentro del arte en general y de la literatura en particular?", Gente vieja, 30 de abril, 1-2.

DELEITO Y PIÑUELA, J. (1911): La tristeza de la literatura contemporánea, Madrid, Tip. de la "Revista de Archivos Bibl. y Museos", 53 p.

DELEITO Y PIÑUELA, J. (1922): El sentimiento de tristeza en la literatura contemporánea, Barcelona, Minerva, $446 \mathrm{p}$.

DIEGO, R. de y VÁZQUEZ, L. (Eds.) (1998): “Prólogo”, en: Humores negros. Del tedio, la melancolía, el esplín y otros aburrimientos, Madrid, Biblioteca Nueva, 11-30.

DUMAS, G. (1900): La tristesse et la joie, Paris, Félix Alcan, 426 p.

ESTEBAN MATEO, L. (1990): El Krausismo, la Institución Libre de Enseñanza y Valencia, Valencia, Nau Llibres, $184 \mathrm{p}$.

FIERENS-GEVAERT, H. (1900): La tristeza contemporánea. Ensayo sobre las grandes corrientes morales e intelectuales del siglo XX. Versión castellana de A. Torres, Madrid, Imp. Del Asilo de Huérfanos del S. C. de Jesús, 226 p. 
FREUD, S. (1992): "Duelo y melancolía”, en: Obras completas, J. Strachey (Ed.), Tr. J. L. Etcheverry, Buenos Aires, Amorrortu, XIV, 235-246.

GONZÁLEZ SERRANO, U. (1898): “Los misántropos”, Vida Nueva, 10, s. p.

HUYSMANS, J-K. (1986): Allá lejos, Tr. de G. Gómez de la Mata, Barcelona, Bruguera, 375 p.

LÓPEZ MANZANEDO, F. M. (2010): La imaginación en la crítica de fin de siglo, Salamanca, Ediciones Universidad de Salamanca, $199 \mathrm{p}$.

LLANAS AGUILANIEDO, J. M. (1991): Alma contemporánea. Estudio de estética, Huesca, Instituto de Estudios Altoaragoneses, $246 \mathrm{p}$.

MOLLOY, S. (2012): Poses de fin de siglo, Buenos Aires, Eterna Cadencia, p. 256.

NORDAU, M. (1902): Degeneración, Madrid, Sáenz de Jubera y Hermanos, I, 908 p.

POE, E. A. (1973): Filosofía de la composición, en: Ensayos y críticas, Tr. de J. Cortázar, Madrid, Alianza, $317 \mathrm{p}$.

QUEIROZ, E. de (1937): “A decadencia do riso”, en: Notas contemporáneas, Lello, 205-211.

RUIZ TORRES, P. (2005): “Prólogo”, en: Gallardo Fernández, I. Ma, José Deleito y Piñuela y la renovación de la historia en España, Valencia, Servei de Publicacions de la Universitat de València, 3-8.

S/F. (1900): "Notas y reseñas", Revista General Internacional, 30 de enero, 61.

TARDIEU, É. (1903): L'ennui: étude psychologique, Paris, Félix Alcan, 297 p.

VALERA, J. y CAMPOAMOR, R. de (1891): La metafísica y la poesía: polémica, Madrid, Sáenz de Jubera hermanos, $271 \mathrm{p}$.

VERLAINE, P. (2007): Fiestas galantes. Tr. M. Machado, Sevilla, Renacimiento, 247 p.

VERLAINE, P. (1994): Poesía Completa, Edición bilingüe, Tr. R. Hervás, Barcelona, Ediciones 29, II, $175 \mathrm{p}$. 
